\title{
Textural variation in the crustal xenoliths in basic dykes, Western Deccan Volcanic Province, Maharashtra, India: evidence of partial melting and pyrometamorphism
}

\author{
Aishwarya N. Ghole*, Tanuuja Marathe and Sudha Vaddadi \\ Geology Department, Fergusson College, F. C. Road, Pune 411 004, India
}

In flood basalt provinces that cover Precambrian terrains, crustal xenoliths are rare. But when present in lava flows and in intrusives, they provide direct information about the basement composition and upper lithospheric crust. Although dykes hosting xenoliths are not common in Deccan Volcanic Province, there are a few known occurrences of mantle and/or crustal xenoliths in some dykes from Maharashtra and Madhya Pradesh, India. The NE-SW dykes from Western Deccan Volcanic Province of upland Maharashtra host crustal xenoliths exhibiting textural variation. Petrographic studies of these xenoliths were not dealt with in detail earlier. We document here, a detailed petrographic work, signifying the importance of pyrometamorphic changes in xenoliths, to understand the composition and explain the textural variation. Presence of elongated quartz ribbons, neocrystallization, incorporation of basaltic melt into mineral cracks, complex twinning in feldspars, exsolved Fe-oxide and silica melt inclusions represent high temperature effects. Major oxide data is suggestive of peraluminous nature of the xenoliths while high temperature minerals tridymite and mullite observed from X-ray diffractograms indicate pyrometamorphic effects. The original rock is quite completely transformed by various processes like partial melting, incipient hybridization and pyrometamorphism, leaving very little mineralogical and textural traces that give evidence of the original protolith. These processes explain the textural variation observed in these upper crustal xenoliths, which could be termed as buchites or buchite rocks.

Keywords: Crustal xenoliths, Deccan Volcanic Province, dyke, pyrometamorphism, textural variation.

DYKES and other intrusives form an important and significant component of the Deccan basalt magmatism. The dykes in Deccan Volcanic Province (DVP), display three major trends on a regional scale; ENE-WSW to E-W in

*For correspondence. (e-mail: aishwarya.ghole@gmail.com)
Narmada-Tapi region, NNW-SSE to N-S along the west coast and NE-SW in upland Maharashtra Plateau ${ }^{1,2}$. Some of the dykes host a variety of crustal and mantle xenoliths. These xenoliths in lava flows and in intrusives provide direct information about the basement composition and upper lithospheric crust ${ }^{3}$. Although dykes hosting xenoliths are not common in DVP, there are a few known occurrences of mantle and/or crustal xenoliths in some dykes from Maharashtra, such as, quartz and alkali feldspar bearing xenoliths at Sasavne ${ }^{4}$; granite-quartzite rafts at Mandaleshwar ${ }^{5}$; hybrid acid xenoliths from Ahmednagar district ${ }^{6}$; crustal and mantle xenoliths from Murud-Janjira $^{7}$ and granitic xenoliths occurring north of Ranala, Nandurbar district ${ }^{8}$. Crustal xenoliths have been documented from Madhya Pradesh by Randive9 .

The Deccan basalts exposed in north-eastern part of Pune district adjoining Ahmednagar district is intruded by dykes trending NE-SW and a few trending NW-SE. This area forms part of Western Deccan Volcanic Province. The xenoliths were reported in 1991, by Sharma and Warrier $^{10}$ and Vaddadi and Sharma ${ }^{11}$, wherein they had described the textural variation. However, detailed petrographic or geochemical studies of the different xenoliths were not conducted to understand the compositional variation, if any. Based on the initial studies, the xenoliths were identified as rhyolitic and granitic, that exhibited hybridization along the margins ${ }^{6}$.

With this background, in the present study, a detailed petrographic analyses of the xenoliths was done to comprehend and explain the textural variation observed.

\section{Geology - field occurrence of xenoliths}

In the present study, two NE-SW trending xenolith bearing dykes, exposed in the area north of Ane $\left(19^{\circ} 14^{\prime} \mathrm{N}\right.$ and $74^{\circ} 19^{\prime} \mathrm{E}$ ) were studied (Figure 1). The lava flows in the area belong to Ratangad Formation ${ }^{12}$. Along the strike length, the width of the dyke varies from $2.46 \mathrm{~m}$ to $13.03 \mathrm{~m}$. Bifurcation of the dykes can be clearly demarcated in the field by prominent and distinct contacts made 


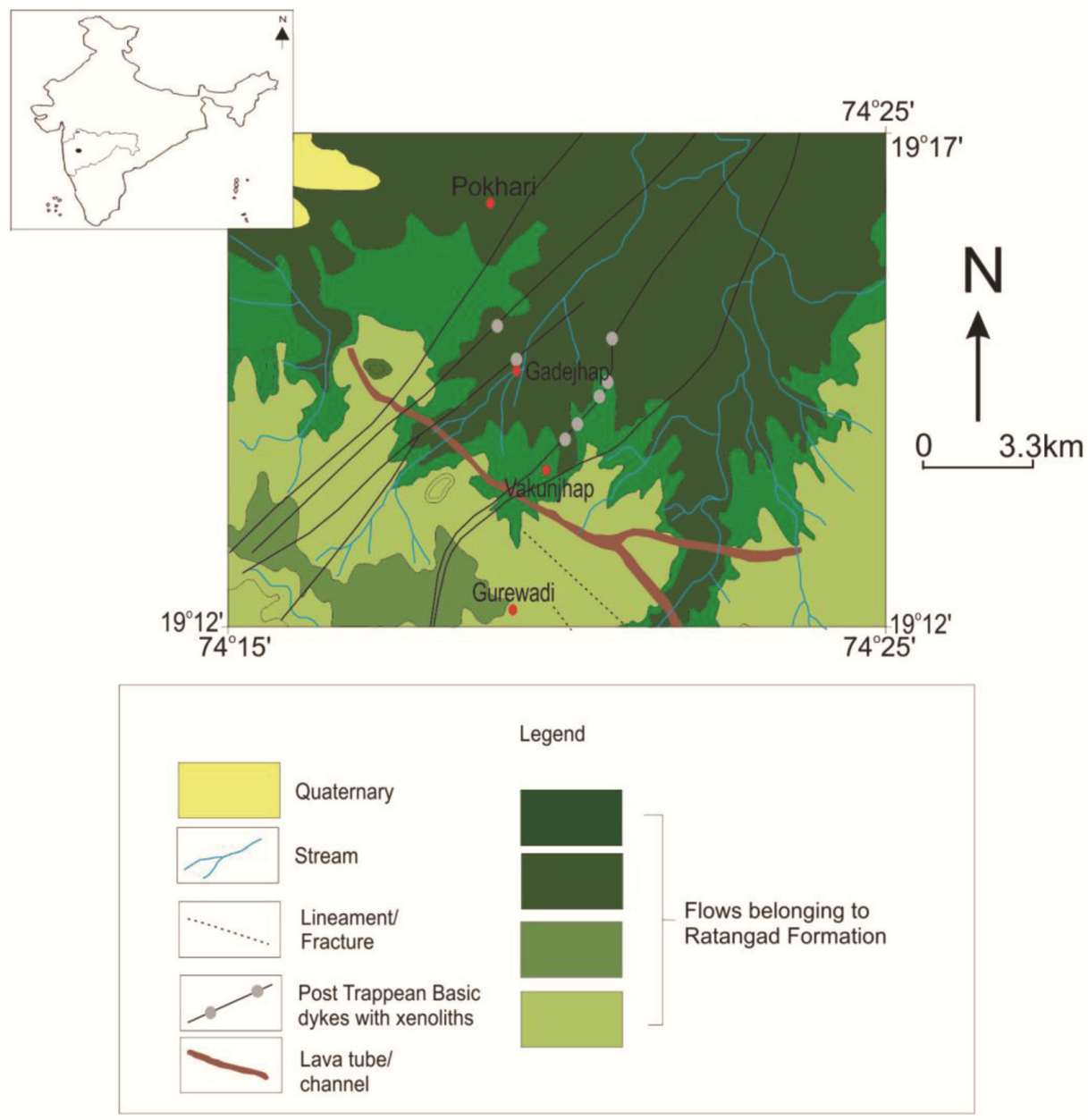

Figure 1. Geological map of the study area. Modified after Sharma and Warrier ${ }^{10}$.

with the host lithology (Figure $2 a-c$ ). The dykes are medium grained, phyric, highly jointed and weathered. The two dykes D1 and D2 (average width being $2 \mathrm{~m}$ and $5.4 \mathrm{~m}$ respectively), host lenticular acidic xenoliths within a strike length of approximately $600-800 \mathrm{~m}$.

Xenoliths are relatively more resistant to weathering and hence stand out in relief; as observed in dyke D1 (Figure $2 d$ and e). Near Vakunjhap $\left(19^{\circ} 14^{\prime} 4.06^{\prime \prime} \mathrm{N}\right.$ and $74^{\circ} 18^{\prime} 45.73^{\prime \prime}$ E), xenolith has a maximum width of $0.8 \mathrm{~m}$ and length of $2.7 \mathrm{~m}$. Xenoliths are fine to coarse grained in texture; dominantly composed of quartz, fine grained material with assimilated margins (Figure $2 g$ and $h$ ).

The dyke D2 exposed near Gadhejhap $\left(19^{\circ} 15^{\prime} 10^{\prime \prime} \mathrm{N}\right.$ and $\left.74^{\circ} 18^{\prime} 14^{\prime \prime} \mathrm{E}\right)$ carries a large xenolith $(9 \mathrm{~m} \times 4.2 \mathrm{~m})$, elongated along its western margin (Figure $2 f$ ). Foliation observed in these xenoliths is due to alternate bands of quartz grains and fine-grained material (Figure $2 i$ ).

\section{Petrography}

Dykes are medium grained, phyric; with glomerocrysts of zoned plagioclase laths (Figure $3 a$ ). The inter-granular and inter-sertal groundmass is constituted of twinned plagioclase feldspars, anhedral augite grains and brownish black coloured glass (Figure $3 b$ ).

Textural variation in the xenoliths is evident from their granitic/equigranularity, pseudo porphyritic and banded/ foliated textures. Quartz and feldspar are the dominant minerals. The inter-granular boundaries are occupied by a mesh of very fine grained brownish microcrystalline and cryptocrystalline aggregate with abundant iron oxide. Photomicrographs of textures of xenoliths in thin sections are shown in Figures 3 and 4 (see colour plates).

Quartz grains are observed as elongated ribbons exhibiting undulose extinction and higher degrees of shattering (Figure $3 c-e$ ). Stress-free neocrystallized quartz grains are visible along the margins of large shattered quartz grains (Figure $3 f$ ). When quartz and feldspar aggregates experience sudden temperature change, they undergo deformation. Under medium grade conditions, quartz behaves as homogeneous medium forming elongated ribbon structures and because of compositional disequilibrium, the melt re-crystallizes bordering the ribbons as neocrystallized grains ${ }^{13}$. These neocrystallized 

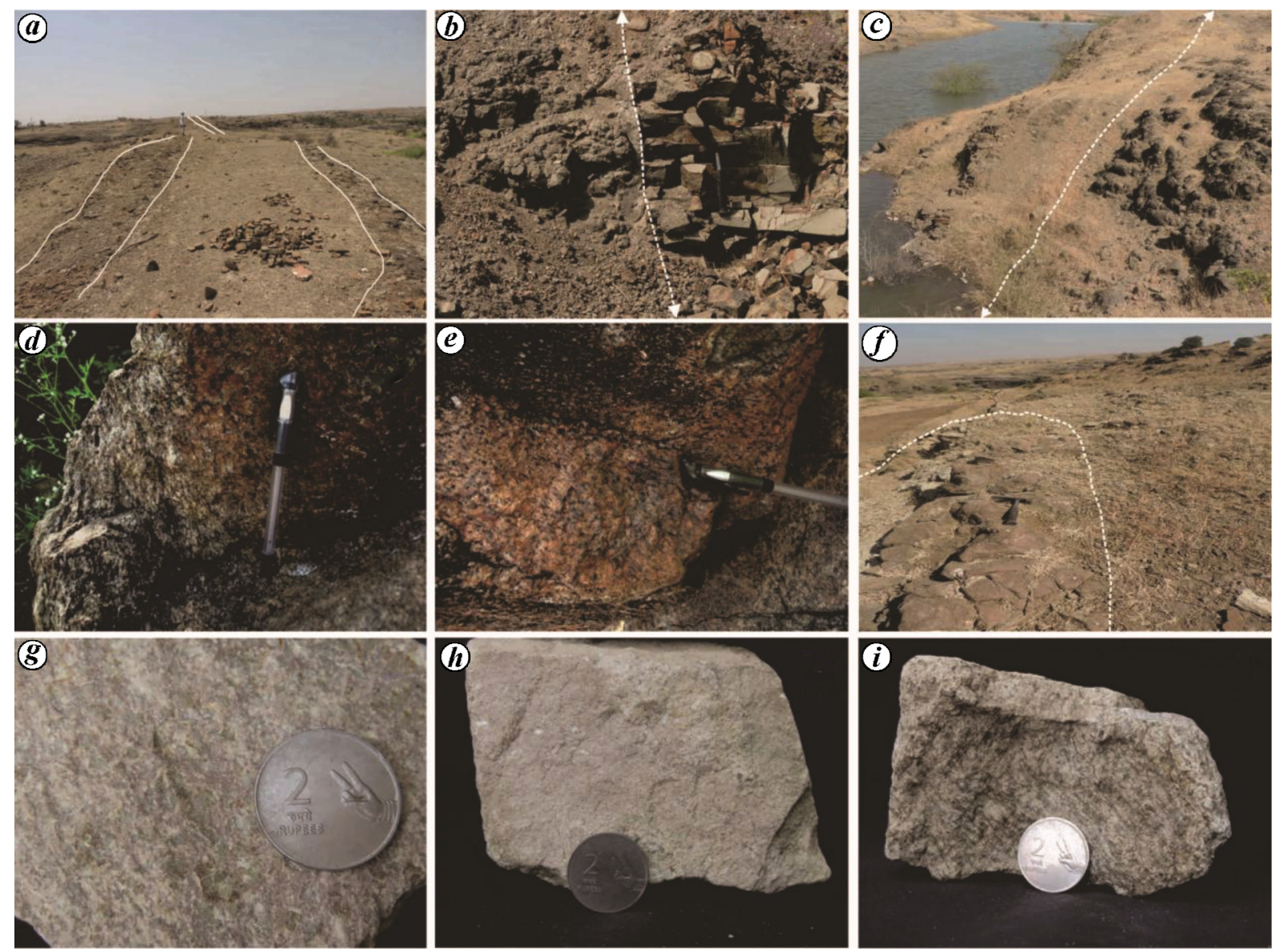

Figure 2. $\boldsymbol{a}$, Bifurcating nature of the dyke D1 and basalt flows. Dyke D1 (b) and dyke D2 (c) making sharp contact with host flows. $\boldsymbol{d}$ and $\boldsymbol{e}$, Field photograph of crustal xenoliths. $\boldsymbol{f}$, A crustal xenolith elongated along the trend of dyke D2. $g$, Xenolith exhibiting coarse grained granulose texture. $\boldsymbol{h}$, Xenolith exhibiting fine grained granulose texture. $\boldsymbol{i}$, Xenolith showing banded structure.

grains are strain free but evident of partial melting effects. The individual quartz grains are rimmed by yellowish-brown isotropic glassy matter, with incorporation of basaltic melt along the cracks which is suggestive of incomplete reaction of the melt with the host rock (Figure $3 j$ and $k$ ). Some quartz grains also exhibit unusual simple twinning as seen in Figure $3 g$ and $h$.

The xenoliths with pseudo porphyritic texture have quartz grains appearing as phenocrysts (varied in size and shape) embedded in isotropic groundmass where the grains show different stages of isotropism like complete isotropism, partial isotropism and undulose extinction resembling isotropic/glassy groundmass at a glance (Figure $4 a$ and $b$ ). The glassy groundmass also exhibits perlitic cracks (Figure $4 c$ ), glass pellets and exsolved opaque Fe-oxide.

Alkali feldspar exhibits temperature dependant unmixing in the form of perthitic inter-growth of $\mathrm{K}$ and $\mathrm{Na}$ feldspar (Figure $4 d$ ). Besides polysynthetic twinning (Figure $4 e$ ), feldspar also exhibits complex twinning (Figure $4 f$ ) suggestive of phase transition from monoclinic K-feldspar to triclinic microcline ${ }^{14}$. Inter-grain boundaries of feldspar show presence of small prismatic, acicular and rectangular grains (Figure $4 g$ ) of mullite, formed as a result of free silica and alumina melt crystallizing at high temperature conditions ${ }^{15,16}$. Crushing and local melting along the feldspar grain boundaries are also observed (Figure $4 h$ ). Feldspar tends to undergo brittle deformation along its cleavage planes ${ }^{13}$. The quartz ribbon cores and feldspar grains exhibiting undulose extinction could be indicative of magmatic stress conditions.

Opaque Fe-oxides under high magnification exhibit anhedral and cubic nature suggesting the probable presence of magnetite and spinel (Figure $3 l$ ).

Presence of highly corroded zircon grains (Figure $4 j$ ), could indicate probable sedimentary provenance. The irregular grains with high relief are of corundum, pointing towards the peraluminous nature of xenolith (Figure $4 k)^{17}$. These grains are observed under high magnification and are inclusions in the smaller grains of feldspars.

Under high magnification, fluid inclusions are observed in large number within the grains of quartz and $\mathrm{K}$ feldspar. The inclusions are either seen along the cracks or cleavages or even disseminated throughout the crystals (Figure $4 l$ ). 

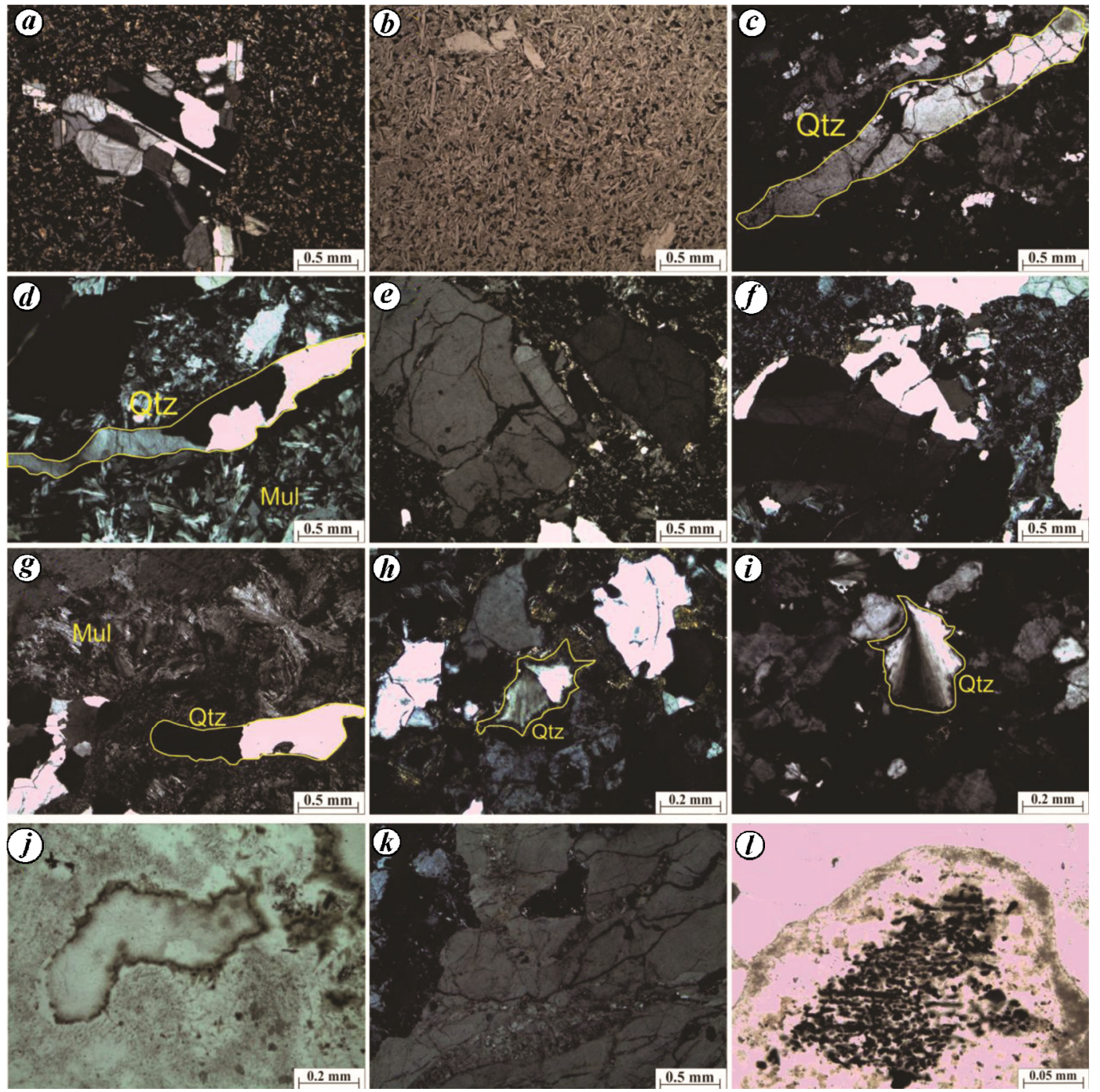

Figure 3. Photomicrographs showing the dyke rock, xenoliths and their interaction. a, Glomeroporphyritic texture shown by dyke hosting xenolith. $\boldsymbol{b}$, Medium grained phyric texture of dyke. $\boldsymbol{c}$ and $\boldsymbol{d}$, Elongated ribbons of quartz showing undulose extinction. $\boldsymbol{e}$, The effects of shattering seen in broken quartz ribbon. $\boldsymbol{f}$, Neo-crystallized quartz grains bordering a bigger quartz grain. $\boldsymbol{g}$, A quartz ribbon exhibiting unusual simple twin and acicular mullite crystals. $\boldsymbol{h}$, Simple twinning shown by a quartz grain. $\boldsymbol{i}$, Strain effects shown by a quartz grain. $\boldsymbol{j}$, A quartz grain rimmed by brown coloured glass. $\boldsymbol{k}$, Incorporation and recrystallization of basalt melt along the cracks. $\boldsymbol{l}$, Globules and strings of Fe-oxide showing linear arrangement. All the photomicrographs are between cross nicols except $\boldsymbol{b}, \boldsymbol{J}$ and $\boldsymbol{l}$. Qtz, Quartz and Mul, Mulllite.

\section{X-ray diffraction analysis}

The XRD analysis was carried out using Bruker D-8 advanced diffractometer at Department of Physics, Savitribai Phule Pune University, Pune. The XRD (Figure 5) shows the plot of intensity versus $2 \theta$, which indicates the presence of high temperature mineral phases of mullite and tridymite, besides orthoclase and $\alpha$-quartz (Table 1). Mullite is typical of pyrometamorphic rocks while tridymite is the high temperature polymorph of quartz ${ }^{16}$. The $d$-spacing values of some peaks partially match with spinel and corundum while some cannot be compared. These could be of non-crystalline or glassy material which does not have a defined crystallographic structure.

\section{Geochemistry}

The chemical analysis of xenolith samples was carried out at the Wadia Institute of Himalayan Geology, Dehradun using the Bruker S-8 Tiger X-ray fluorescence spectrometry. In our study, emphasis was given on the major oxide data as it was considered as a supplementary data for detailed petrographic analysis. It reflected the chemical composition and mineralogy of the rock.

The major oxide data for representative xenolith samples showed limited compositional range of $\mathrm{SiO}_{2}(66.01-$ $77.44 \%) ; \mathrm{Al}_{2} \mathrm{O}_{3}(12.43-17.24 \%) ; \mathrm{K}_{2} \mathrm{O}$ (1.30-9.02\%); $\mathrm{Na}_{2} \mathrm{O}$ (2.22-5.06\%); Cao (0.40-1.18\%); $\mathrm{MgO}$ (0.06$0.33 \%)$ and $\mathrm{Fe}_{2} \mathrm{O}_{3}(0.062-2.17 \%)$. Highly siliceous and aluminous nature of the xenoliths is evident from the 


\section{RESEARCH ARTICLES}
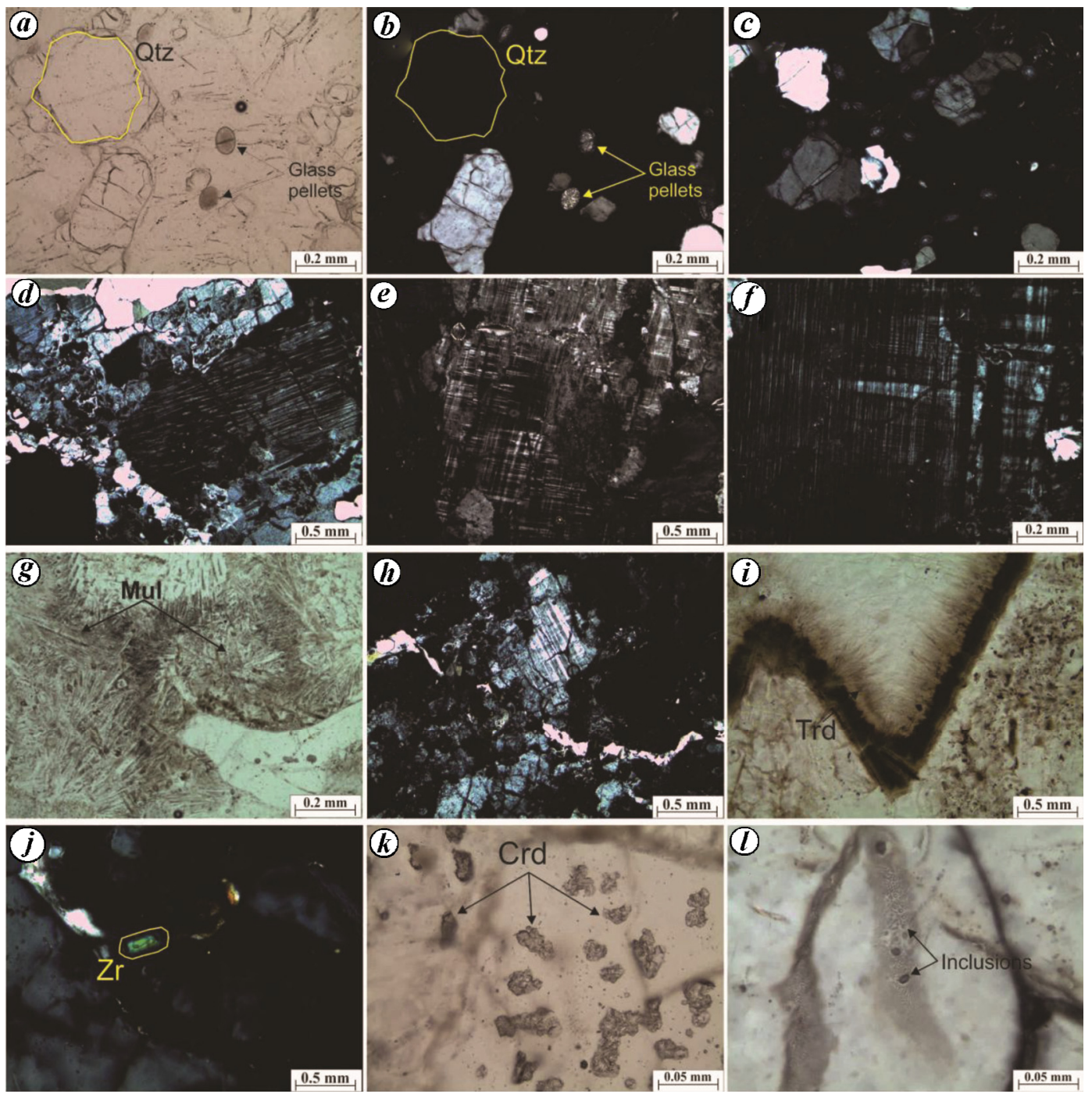

Figure 4. Photomicrographs showing the xenoliths and their alteration effects during emplacement. $\boldsymbol{a}$ and $\boldsymbol{b}$ Pseudoporphyritic texture; quartz grains exhibiting high relief and some showing unusual isotropic behaviour. Groundmass is characterized by presence of glass pellets and perlitic cracks. $c$, Quartz grains exhibiting different stages of extinction along with some glass pellets and perlitic cracks in the groundmass. $\boldsymbol{d}$, K-feldspar showing perthitic intergrowth and crushing effects. $\boldsymbol{e}$, Polysynthetic twinnig exhibited by alkali feldspar. $\boldsymbol{f}$, Feldspar grain exhibiting complex twinnig. $\boldsymbol{g}$, Acicular mullite crystals. $\boldsymbol{h}$, Crushing and local melting observed along grain boundaries. $\boldsymbol{i}$, Tridymite bordering quartz grain. $\boldsymbol{j}$, Zircon (Zr) grain having high order interference colours. $\boldsymbol{k}$, Irregular inclusions of corundum into feldspar. $\boldsymbol{l}$, Presence of fluid inclusions in quartz and feldspar grains. All the photomicrographs are between cross nicols except $\boldsymbol{a}$, $\boldsymbol{g}, \boldsymbol{i}, \boldsymbol{k}$ and $\boldsymbol{l}$. Qtz, Quartz; Mul, Mullite; Trd, Tridymite; Zr, Zircon and Crd, corundum.
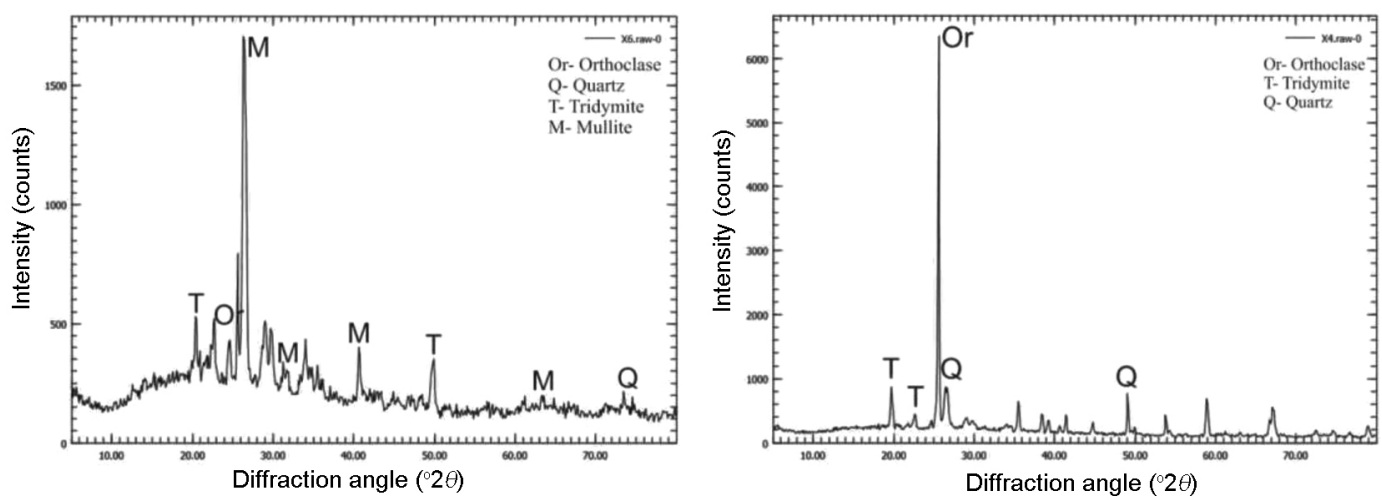

Figure 5. X-ray diffractogram of xenoliths. 
Table 1. X-ray diffraction analysis of the xenolith samples

\begin{tabular}{llll}
\hline Reference code & Compound name & Chemical formula & Remarks \\
\hline X4 & Orthoclase & $(\mathrm{K}, \mathrm{Na}) \mathrm{AlSi}_{3} \mathrm{O}_{8}$ & Major \\
& Tridymite & $\mathrm{SiO}_{2}$ & Minor \\
& Quartz & $\mathrm{SiO}_{2}$ & Minor \\
X6 & Mullite & $3 \mathrm{Al}_{2} \mathrm{O}_{3} \cdot 2 \mathrm{SiO}_{2}$ & Major \\
& Tridymite & $\mathrm{SiO}_{2}$ & Major \\
& Quartz & $\mathrm{SiO}_{2}$ & Minor \\
& Orthoclase & $(\mathrm{K}, \mathrm{Na}) \mathrm{AlSi}_{3} \mathrm{O}_{8}$ & Minor \\
\hline
\end{tabular}

Table 2. Major oxide (wt $\%$ ) data of xenoliths

\begin{tabular}{lccccccccccc}
\hline & X1 & X2 & X3 & X4 & X5 & X6 & X7 & X8 & X9 & X10 & X11 \\
\hline $\mathrm{SiO}_{2}$ & 77.44 & 74.92 & 69.04 & 72.58 & 74.9 & 74.94 & 66.01 & 74.72 & 70.08 & 59.85 & 66.63 \\
$\mathrm{Al}_{2} \mathrm{O}_{3}$ & 12.43 & 13.02 & 15.93 & 15 & 12.76 & 12.93 & 17.34 & 13.25 & 14.45 & 15.59 & 13.58 \\
$\mathrm{~K}_{2} \mathrm{O}$ & 6.56 & 1.3 & 9.02 & 4.73 & 4.52 & 5.66 & 7.19 & 5.78 & 5 & 5.37 & 4.25 \\
$\mathrm{Na}_{2} \mathrm{O}$ & 2.22 & 5.06 & 3.35 & 4.46 & 4.06 & 2.94 & 4.24 & 3.03 & 3.5 & 3 & 3.25 \\
$\mathrm{CaO}$ & 0.42 & 0.94 & 0.4 & 0.81 & 0.75 & 1.01 & 1.18 & 0.74 & 1.12 & 3.22 & 2.52 \\
$\mathrm{MgO}$ & 0.06 & 0.12 & 0.06 & 0.21 & 0.2 & 0.22 & 0.33 & 0.25 & 1.2 & 1.6 & 1 \\
$\mathrm{TiO}_{2}$ & 0.02 & 0.07 & 0.06 & 0.15 & 0.16 & 0.2 & 0.26 & 0.24 & 0.37 & 0.87 & 0.56 \\
$\mathrm{P}_{2} \mathrm{O}_{5}$ & 0.01 & 0.01 & 0.01 & 0.03 & 0.03 & 0.03 & 0.03 & 0.04 & 0.05 & 0.05 & 0.04 \\
$\mathrm{Fe}_{2} \mathrm{O}_{3}$ & 0.06 & 0.42 & 0.19 & 1.47 & 1.42 & 1.12 & 2.19 & 1.02 & 2.4 & 4.5 & 2.2 \\
$\mathrm{MnO}$ & $\mathrm{BDL}$ & 0.01 & $\mathrm{BDL}$ & 0.01 & 0.01 & 0.01 & 0.02 & 0.01 & 0 & 0 \\
$\mathrm{SUM}$ & 99.22 & 95.87 & 98.06 & 99.45 & 98.81 & 99.06 & 98.79 & 99.08 & 98.17 & 94.05 & 94.03 \\
$\mathrm{LOI}$ & 0.89 & 6.11 & 1.02 & 1.59 & 1.41 & 2.55 & 2.87 & 2.26 & 1.74 & 5.64 & 6.14 \\
\hline
\end{tabular}

chemical data (Table 2). Normative corundum is also indicative of peraluminous nature of all samples. In the total alkali silica classification scheme ${ }^{18}$, most of the xenoliths straddle between rhyolite and trachyte fields, suggesting silicic nature. Some lie on trachy-andesite and dacite field boundary suggesting higher degrees of assimilation of basaltic melt. On the ternary plots of $\mathrm{ACF}^{19}$, xenolith samples mainly occupy the quartzofeldspathic field and in some plots, adjacent to the pelitic field. As the xenolith samples are aluminous in nature, the chemical data was plotted on $\mathrm{Al}_{2} \mathrm{O}_{3}-\mathrm{SiO}_{2}-\mathrm{FeO} / \mathrm{MgO} / \mathrm{TiO}_{2}$ ternary diagram ${ }^{19,20}$; where in they indicate mullite and tridymite phases.

\section{Discussion and conclusion}

Xenoliths open a window to speculate about subsurface petrology, whether crustal or mantle. Xenoliths once incorporated in host magma undergo reaction, solution, melting and/or re-crystallization and thereby get assimilated to different extents. The extent of assimilation is influenced by the nature of xenolith, its residence time, magma composition and the temperature of intruding magma. The mineralogy of the xenoliths in the present study, does not match with the mantle petrology as it essentially contains quartz and feldspar mineral phases and hence termed as crustal.

The petrographic observations highlight the high temperature and stress conditions experienced by the xenoliths. Shattering and microcracking along with melting and partial isotropism in the grains have resulted due to volume increase on vitrification. The glass occupies the interspaces between the grains while rounded quartz and felspar grains show embayment at their contact with glass - a common feature in buchites with melt content $<45 \%$ (ref 21). Complex twinning observed in the feldspars is indicative of phase transition ${ }^{14}$.

Textural and compositional heterogeneities observed could be due to processes like mixing and partial melting that might have occurred between the host magma and xenoliths, as suggested by Del Moro et al. ${ }^{15}$. Additionally, the presence of fine mullite crystals is indicative of high temperature. Mineral phases of mullite, tridymite, orthoclase, $\alpha$-quartz with minor spinel and corundum, identified in the X-ray diffractogram, compliment the petrographic observations. Mullite is typical of contact metamorphism and pyrometamorphism ${ }^{21}$. Re-crystallization or devitrification into mullite and tridymite grains along grain boundaries and presence of fluid inclusions in quartz grains also point towards further pyrometamorphic effects. The xenoliths from the study area can thus be referred to as buchites and/or buchite rocks formed as a result of pyrometamorphism. Randive ${ }^{9}$ commented upon the polymorphic transformation of the xenoliths found in Lamprophyre and Picrobasalt dykes from Bakhatgarh-Phulmal area, Jhabua district, Madhya Pradesh. He also stated that these mineral transformations and restructuring could be due to different pressure-temperature conditions inside magma.

The opaques exhibiting various patterns and occurring along the cleavages of altered mineral grains could be of magnetite or spinel. Presence of opaque minerals in xenoliths can be attributed to dissolution or breakdown of a $\mathrm{Fe}-\mathrm{Mg}$ rich mineral phase present during emplacement. 
According to Frezzotti et $a .^{22}$, silica melt trapped as inclusions in crustal xenoliths may preserve melt produced during anatexis. They have reported significant quantities of colourless glass, both as films along the grain boundaries and as silica melt inclusions within single quartz grains in the quartz rich xenoliths from Vulcano Island, Southern Italy. Small blebs resembling melt inclusions occur within quartz grains in some of the xenoliths studied. The xenoliths occurring in the basic dykes are formed due to different degrees of partial melting of the crustal rocks. In the Western Deccan Volcanic Province, Precambrian rocks (granites, granitic gneisses and other metamorphic) and Neoproterozoic sediments (sandstone and shale) are likely the basement rocks. The dykes intruding the basalts could host fragments of the above mentioned rocks.

Ray et $a l^{3}$ based on geochemistry of xenoliths found in Rajmane dyke south of Dhule, suggested the extension of Dharwar Craton below DVP further north. Based on the petrographic observations it is difficult to ascertain that the protolith is igneous. However, highly corroded zircon grains present in a few samples could be of probable sedimentary origin. Growth boundaries, growth zones and inter-granular spaces are significant textural elements and based on the present study, it is observed that the original rock is almost completely transformed by various processes like partial melting, incipient hybridization and pyrometamorphism, leaving very little mineralogical and textural traces that give evidence of the original protolith. This could explain the textural variation observed in these xenoliths. These pyrometamorphosed quartzofeldspathic xenoliths are characterized by the presence of tridymite, mullite, corundum, opaque iron oxides (spinel, magnetite) and could be termed as buchites or buchite rocks. Further studies and extensive work is required to comment upon the accurate nature of protolith for xenolith.

1. Auden, J. B., Dykes in the western India - a discussion on their relationships with the Deccan Traps. Trans. Nat. Inst. Sci., 1949, 3, 123-157.

2. Deshmukh, S. S. and Sehgal, M. N., Mafic dyke swarms in the Deccan volcanic province of Madhya Pradesh and Maharashtra. Mem. Geol. Soc. India, 1988, 10, 323-340.

3. Ray, R. et al., Highly heterogeneous Precambrian basement under the central Deccan Traps, India: direct evidence from xenoliths in dykes. Gondwana Res., 2008, 13, 375-385.

4. Dessai, A. G. and Viegas, A. A. A., Multi-generation mafic dyke swarm related to Deccan magmatism, south of Bombay: implications on the evolution of the western Indian continental margin. Mem. Geol. Soc. India, 1995, 33, 435-451.

5. Duraiswami, R. A. and Karmalkar, N. R., Unusual xenolithic Dyke at Mandaleshwar and its episodic nature. Gondwana Geol. Mag., 1996. 11(1), 1-10.

6. Sharma, R. K., Pandit, M. K. and Warrier, S., Hybrid acid xenoliths in dolerite dykes intruding Deccan Flood Basalts, PuneAhmednagar Region, Western India. J. Geol. Soc. India, 1999, 54, 303-308.

7. Dessai, A. G., Markwick, A., Vaselli, O. and Downes, H., Granulite and pyroxenite xenoliths from the Deccan Trap: insight into the nature and composition of the lower lithosphere beneath cratonic India. Lithos, 2004, 78, 263-290.

8. Sen, B. and Sabale, A. B., Unpublished Interim Report on Petrological and Petrochemical Study of Dyke Swarms and Related Intrusives of Northern Maharashtra (parts of Toposheets $46 \mathrm{~K} / 3,4,7$ and 8), 2008, p. 54.

9. Randive, K. R., Occurrence of xenoliths in the lamprophyre and picrobasalt dykes of Bakhatgarh - Phulmal area, Jhabua district, Madhya Pradesh, India. In Dyke Swarms: Keys for Geodynamic Interpretation, Chapter 18 (ed. Srivastava, R. K.), Springer-Verlag Berlin, Heidelberg, 2011, pp. 301-313.

10. Sharma, R. K. and Warrier, S., Geology of parts of Junnar, Ambegaon and Shirur talukas of Pune district and Sangamner tehsil of Ahmednagar district, Maharashtra. Unpublished Progress Report for FS 1989-90, Geological Survey of India, 1991.

11. Vaddadi, S. and Sharma, R. K., Occurrence of xenoliths of hybrid nature in basic dyke, Pune and Ahmednagar distorts, Maharashtra (abstract). Gondwana Geol. Mag. Spl., 1996, 2, 538.

12. Vaidyanathan, R. and Ramakrishnan, M., Geology of India. Geol. Soc. Ind., 2010, 2, 755.

13. Passchier, C. W. and Trouw, R. A. J., Microtectonics, Springer, Berlin, 2005, 2nd edn, p. 322.

14. Deer, W. A., Howie, R. A. and Zussman, J., An Introduction to the Rock-Forming Minerals, Longman, London, UK, 1966, p. 528.

15. Del Moro, S., Renzulli, A. and Tribaudino, M., Pyrometamorphic processes at the magma hydrothermal system interface of active volcanoes: evidence from buchite ejecta of Stromboli (Aeolian Islands, Italy). J. Petro., 2011, 52(3), 541-564.

16. Kerr, P. F., Optical Mineralogy, McGraw Hill, NY, USA, 1959, 3rd edn, p. 425.

17. William, H., Turner, F. J. and Gilbert, C. M., Petrography $-A n$ Introduction to the Study of Rocks in Thin Sections, W.A., Freeman, San Francisco, USA, 1954, p. 406.

18. Eskola, P., On the relations between the chemical and mineralogical composition in metamorphic rock of the Orijarvi region, 1915. In An Introduction to Igneous and Metamorphic Petrology (ed. Winter, J. D.), Prentice-Hall Inc, Upper Saddle River, New Jersey, 2001.

19. Ortega-Gutiérrez, F., Martiny, B. M., Morán-Zenteno, D. J., Reyes-Salas, A. M. and Solé-Viñas, J., Petrology of very high temperature crustal xenoliths in the Puente Negro intrusion: a sapphire-spinel-bearing oligocene andesite, Mixteco terrane, southern Mexico. Rev. Mex. Cienc. Geol., 2011, 28(3), 593-629.

20. Grapes, R. H., Pyrometamorphism, Springer, Berlin, 2006, p. 269.

21. Markl, G., Mullite-corundum-spinel-cordierite-plagioclase xenoliths in the Skaergaard Marginal Border Group: multi-stage interaction between metasediments and basaltic magma. Contrib. Min. Petrol., 2005, 149, 196-215.

22. Frezzotti, M.-L., Peccerillo, A., Zanon, V. and Nikogosian, I., Silica-rich melts in quartz xenoliths from Vulcano Island and their bearing on processes of crustal anatexis and crust-magma interaction beneath the Aeolian Arc, Southern Italy. J. Petrol., 2004, 45(1), 3-26.

ACKNOWLEDGEMENTS. We acknowledge Wadia Institute of Himalayan Geology, Dehradun, for permitting to use the XRF facility for geochemical analysis. We would also like to thank Savitribai Phule Pune University, Physics Department, for providing with XRD analysis. We thankful to Dr Ravindrasinh Pardeshi, Mr Anupam Gokhale, Mr Chinmay Thite and Mr. Kalpajit Kalita for their generous help and support. We also thank the anonymous reviewers for their constructive suggestions.

Received 1 June 2019; revised accepted 18 July 2019

doi: $10.18520 / \mathrm{cs} / \mathrm{v} 117 / \mathrm{i} 8 / 1333-1339$ 